\title{
Different Susceptibilities between Apoe- and Ldlr-Deficient Mice to Inflammation-Associated Colorectal Carcinogenesis
}

\author{
Takuji Tanaka $^{1,2, *}$, Takeru Oyama ${ }^{3}$, Shigeyuki Sugie ${ }^{4}$ and Masahito Shimizu ${ }^{5}$ \\ 1 Department of Diagnostic Pathology (DDP) and Research Center of Diagnostic Pathology (RC-DiP), \\ Gifu Municipal Hospital, 7-1 Kashima-cho, Gifu City, Gifu 500-8513, Japan \\ 2 Department of Tumor Pathology, Gifu University Graduate School of Medicine, 1-1 Yanagido, Gifu City, \\ Gifu 501-1194, Japan \\ 3 Department of Molecular and Cellular Pathology, Graduate School of Medical Science, Kanazawa University, \\ Kanazawa, Ishikawa 920-8640, Japan; takeruoyama@staff.kanazawa-u.ac.jp \\ 4 Department of Pathology, Murakami Memorial Hospital, Asahi University, School of Dentistry, \\ 3-23 Hashimoto-cho, Gifu City, Gifu 500-8523, Japan; sugie@murakami.asahi-u.ac.jp \\ 5 Department of Gastroenterology/Internal Medicine, Gifu University Graduate School of Medicine, \\ 1-1 Yanagido, Gifu City, Gifu 501-1194, Japan; shimim-gif@umin.ac.jp \\ * Correspondence: takutt@gmhosp.gifu.gifu.jp; Tel.: +81-58-215-8525
}

Academic Editor: Terrence Piva

Received: 1 August 2016; Accepted: 19 October 2016; Published: 28 October 2016

\begin{abstract}
Hypercholesterolemia resulting in atherosclerosis is associated with an increased risk of ischemic heart disease and colorectal cancer (CRC). However, the roles of apoliprotein (Apo) E (Apoe) and low-density lipoprotein $(\mathrm{Ldl})$ receptor $(\mathrm{Ldlr})$ in colorectal carcinogenesis have not yet been investigated. In this study, we examined the susceptibility of Apoe-deficient and Ldlr-deficient mice, which are genetic animal models of atherosclerosis to azoxymethane (AOM)/dextran sodium sulfate (DSS)-induced colorectal carcinogenesis. In Experiment 1, male Apoe-deficient $(n=20)$ and wild type (WT) mice (C57BL/6J, $n=21$ ) were treated with a single intraperitoneal (i.p.) injection of AOM (10 mg/kg body weight) and then given $1.5 \%$ DSS in drinking water for seven days. They were maintained up to week 20 and sacrificed for the histopathological examination of colorectal tumors. The mRNA expression of cyclooxygenase (Cox)-2, inducible nitric oxide synthase (Nos2), tumor necrosis factor (Tnf)- $\alpha$ interleukin (Il)-1 $\beta$, and Il- 6 was assayed in the colorectal mucosa. In Experiment 2, male $L d l r$-deficient $(n=14)$ and WT mice (C57BL/6J, $n=10)$ were given a single i.p. injection of AOM (10 mg/ $\mathrm{kg}$ body weight) and then given $2 \%$ DSS in drinking water for seven days. They were sacrificed at week 20 to evaluate their colorectum histopathologically. In Experiment 1, the multiplicity of CRCs was significantly higher in the Apoe-deficient mice $(2.75 \pm 1.48)$ than in the WT mice $(0.62 \pm 0.67)$. The serum lipoprotein levels in the Apoe-deficient mice were also significantly higher than in the WT mice. In Experiment 2, the incidence (29\%) and multiplicity $(0.50 \pm 0.94)$ of CRCs in the Ldlr mice were significantly lower than in the WT mice $(80 \%$ incidence and $3.10 \pm 2.38$ multiplicity). The mRNA expression of two inducible enzymes and certain pro-inflammatory cytokines in the colorectum of each genotype was greater than in the respective WT mice. The values in the Apoe-deficient mice were much greater than in the Ldlr mice. These findings suggest that Apoe-deficient mice showed increased susceptibility to inflammation-associated colorectal carcinogenesis due to their high reactivity to inflammatory stimuli.
\end{abstract}

Keywords: Apoe; Ldl receptor; genetically altered mice; serum lipid profiles; inflammation; colorectal carcinogenesis 


\section{Introduction}

Colorectal cancer $(\mathrm{CRC})$ is the second-most common malignancy worldwide in women and the third-most common malignancy in men [1], although global CRC incidence and mortality have marked variation $[1,2]$. CRC occurs initially by mutation of the tumor suppressor gene, $A P C$, and thereafter via the accumulation of other genetic mutations in a step-wise process over several years [3]. Both hereditary and environmental factors contribute to CRC development [3]. Dietary factors play a particularly important role in colorectal carcinogenesis [3-5]. While diets high in red meat and processed meat can increase the risk of $C R C$, diets rich in fruits, vegetables, and fiber reduce the CRC risk [6-9]. Animal fat is known to be one of the risk factors for CRC [10,11]. Genetic alterations involving the lipid transportation and its metabolism are also susceptibility factors for CRC [12].

Inflammatory bowel disease (IBD), including Crohn's disease (CD) and ulcerative colitis (UC), has emerged as a global disease with increasing incidence and prevalence in the world $[13,14]$. Although the precise etiology of IBD is not known, immune dysregulation induced by genetic and/or environmental factors plays an important role in this complex multifactorial disease [15]. Hyper-inflammation status, such as with chronic hepatitis C or B, reflux esophagitis, and IBD, increases the risk of cancer development in the inflamed tissues [16]. Inflammation also strongly promotes carcinogenesis [17]. Inflammatory mediators, including cytokines, chemokines, reactive oxygen/nitrogen species, prostaglandins, growth and transcription factors, microRNAs, and enzymes (cyclooxygenase and matrix metalloproteinase), collectively establish a microenvironment that is favorable for cancer development through an extensive and dynamic crosstalk with tumor cells. They could cause DNA damage (initiation) and affect the stages of tumor promotion and progression.

Apoe (34KD-MW protein) is the protein product of a single gene mapped to the long arm of chromosome 19q $[18,19]$. This 50 kilobases $(\mathrm{kb})$ gene cluster includes the genes for apolipoprotein C-I and C-II involved in the regulation of the metabolism of plasma lipoprotein [18,19]. Apoe contains 299 residues and plays an important role in mediating receptor-dependent lipoprotein uptake. The receptors involved in lipoprotein uptake mediated by Apoe are the low-density lipoprotein receptor (Ldlr) and the chylomicron remnant receptor, the latter being also referred to as the Ldlr-related protein (LRP) [20]. The Ldlr is considered to be ubiquitously expressed in mammals, although the bulk of receptor-dependent clearance of LDL is shown to occur through the liver [20,21]. Although there is little information on the distribution of these receptors in human colonic crypt cells, Ldlr is reported to be present in the crypt cells in rat small intestine [22]. In addition, small intestinal crypt cells in rats are able to uptake chylomicron remnants receptor-dependently [23].

Apoe may influence CRC development via three potential pathways. They include (1) metabolism of cholesterol and bile acid; (2) regulation of triglycerides (TG) and insulin; and (3) inflammation. Apoe involved in lipid metabolism may affect the absorption of luminal cholesterol and bile acid metabolism [24-26]. Possessing an e4 Apoe allele may increase the risk of gallstones formation [27,28]. Bile acid is important in CRC development. People with gallstones are at a higher risk of developing proximal colon cancer than those without [29]. Variants of Apoe affect serum levels of lipid and/or triglyceride and insulin sensitivity [30,31]. TG and insulin are known to be involved in CRC development $[32,33]$. The third pathway via which Apoe regulates CRC development is colonic inflammation [34,35]. Both a high-fat diet and obesity are associated with CRC development [7,36,37].

CRCs contain high levels of fatty acids or their products stored in cancer cell membranes. This suggests a certain role of fatty acids in colorectal carcinogenesis [38,39]. Linoleic acid is converted to arachidonic acid (AA), which is further biosynthesized into prostaglandins (PGs). The Ldlr regulates the uptake of essential fatty acid and cholesterol into cells. Then, the essential polyunsaturated fatty acids are esterified to phospholipids. AA released from phospholipids is oxidized by cytochrome P-450 (Cyp), lipoxygenase (Lox), or cyclo-oxygenase (Cox). Through the Cox pathway, various PGs, including $\mathrm{PGE}_{2}$ are produced. Ldlr plays an important role in the initial uptake of essential fatty acid and the subsequent biosynthesis of eicosanoids, such as PGE 2 [40,41]. Thus, epidemiological and experimental data suggest fatty acids as an important factor in the CRC development. Over-expression 
of Cox-2, an inducible inflammatory enzyme that metabolizes the essential fatty acids into PGs, in CRC was first observed in 1994 [42], and thereafter the concept of chemoprevention using Cox inhibitors was proposed [42-46].

Certain cancers, including CRC and human cancer cell lines, have increased levels in Ldlr protein [47,48]. A loss of feedback regulation of Ldlr in CRCs was also reported [49]. In addition, Cox-2 was up-regulated in colorectal neoplasms that over-expressed L $d l r$ mRNA compared with normal colorectal mucosa. These findings may suggest that $L d l r$ is abnormally regulated in tumors and may play a certain role in the up-regulation of Cox-2 in neoplasms.

Alterations in the plasma lipid profiles and in intracellular cholesterol homoeostasis were reported in various malignancies, including CRCs. However, the significance of these alterations, if any, in colorectal carcinogenesis and cancer biology is not clear. In the current study, we examined whether or not Apoe and Ldlr were involved in colorectal carcinogenesis in mice. For this, we used an inflammation-associated colorectal carcinogenesis model of Apoe- or Ldlr-deficient mice developed with azoxymethane (AOM) and promoted by dextran sodium sulfate (DSS), where many colorectal neoplasms develop within a short period of time [50].

\section{Results}

\subsection{AOM/DSS-Induced Colorectal Carcinogenesis in the Apoe-Deficient Mice (Experiment 1)}

Both the Apoe-deficient mice and WT mice tolerated treatment with AOM and 1.5\% DSS well and survived to week 20 (Figure 1a). As listed in Table 1, at sacrifice, the body $(p<0.05)$ and liver weights $(p<0.001)$ of the Apoe-deficient mice were significantly greater than those of the WT mice. The mean relative liver weights of both groups were comparable. When given AOM and DSS, the colon length of the Apoe-deficient mice was slightly shorter than that of the wild type of mice (Table 1). Treatment with AOM followed by $1.5 \%$ DSS resulted in the development of colorectal tumors in both genotypes (Figure 2a). The incidences and multiplicities of several colorectal lesions, such as mucosal ulcer, adenoma (AD), and AD + adenocarcinoma (ADC), were larger in the Apoe-deficient mice than in the WT mice, but the differences between the two genotypes were not significant (Table 2). In addition, the multiplicities of dysplastic lesions (DYS) and ADC in the Apoe-deficient mice were also larger than in the WT mice, and these differences were statistically significant (dysplastic lesions, $p<0.02$; and ADC, $p<0.005$, Table 2). The mean volume $\left(1150.2 \pm 396.7 \mathrm{~mm}^{3}\right)$ of colorectal tumors in the Apoe-deficient mice was significantly greater than that $\left(597.9 \pm 234.6 \mathrm{~mm}^{3}\right)$ in the WT mice $(p<0.05)$, as shown in Figure 3a. Histopathologically, three types (well, moderately, and poorly) of differentiation were observed in ADCs (Figure 4a). Poorly differentiated adenocarcinomas developed in a few Apoe-deficient mice that received AOM and DSS (Figure 4b). The incidence and multiplicity of mucosal ulcer in the Apoe-deficient mice were higher than in the WT mice, but the differences were not statistically significant (Table 2).

Table 1. Body weight, liver weights, and colon length.

\begin{tabular}{ccccc}
\hline Measurements & $\begin{array}{c}\text { Apoe-Deficient } \\
\text { Mice }(\boldsymbol{n}=\mathbf{2 0})\end{array}$ & $\begin{array}{c}\text { WT Mice } \\
(\boldsymbol{n}=\mathbf{2 1})\end{array}$ & $\begin{array}{c}\text { Ldlr } \text {-Deficient } \\
\text { Mice }(\boldsymbol{n}=\mathbf{1 4})\end{array}$ & $\begin{array}{c}\text { WT Mice } \\
(\boldsymbol{n}=\mathbf{1 0})\end{array}$ \\
\hline Body weight $(\mathrm{g})$ & $34.1 \pm 2.2^{\mathrm{a}, \mathrm{b}}$ & $31.4 \pm 3.5$ & $30.1 \pm 3.1^{\mathrm{b}}$ & $32.6 \pm 1.7$ \\
Liver weight $(\mathrm{g})$ & $1.31 \pm 0.07^{\mathrm{c}}$ & $1.14 \pm 0.09$ & $1.43 \pm 0.13^{\mathrm{d}}$ & $1.60 \pm 0.22$ \\
\% Liver weight (Liver weight/100 g body weight) & $3.77 \pm 0.33$ & $3.69 \pm 0.36$ & $4.78 \pm 0.28$ & $4.91 \pm 0.52$ \\
Colon length $(\mathrm{cm})$ & $12.35 \pm 0.90$ & $12.50 \pm 0.90$ & $10.09 \pm 0.62$ & $10.4 \pm 0.72$ \\
\hline
\end{tabular}

WT, wild type. ${ }^{\mathrm{a}}$ Mean \pm standard deviation (SD); ${ }^{\mathrm{b}-\mathrm{d}}$ Significantly different from the respective WT mice $\left({ }^{\mathrm{b}} p<0.05,{ }^{\mathrm{c}} p<0.001\right.$, and $\left.{ }^{\mathrm{d}} p<0.01\right)$. 
(a)

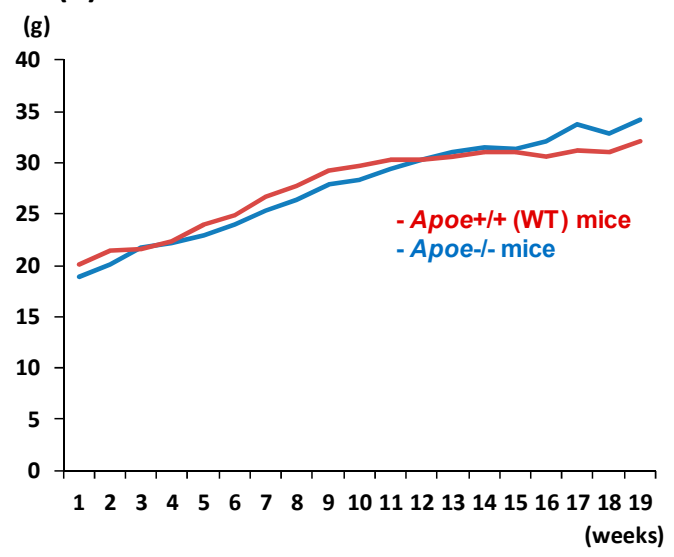

(b)

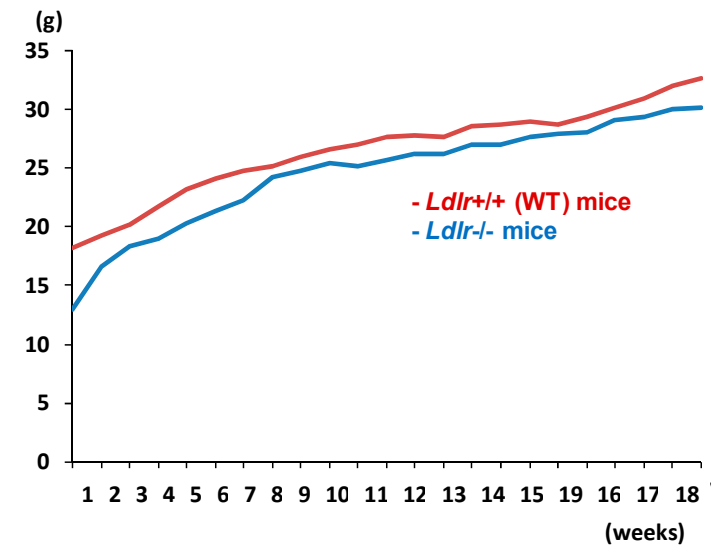

Figure 1. The body weight changes of (a) the Apoe-deficient and wild type (WT) mice during Experiment 1 and (b) the low-density lipoprotein receptor $(L d l r)$-deficient and WT mice during Experiment 2.

(a) Apoe $^{-I-}$ mice

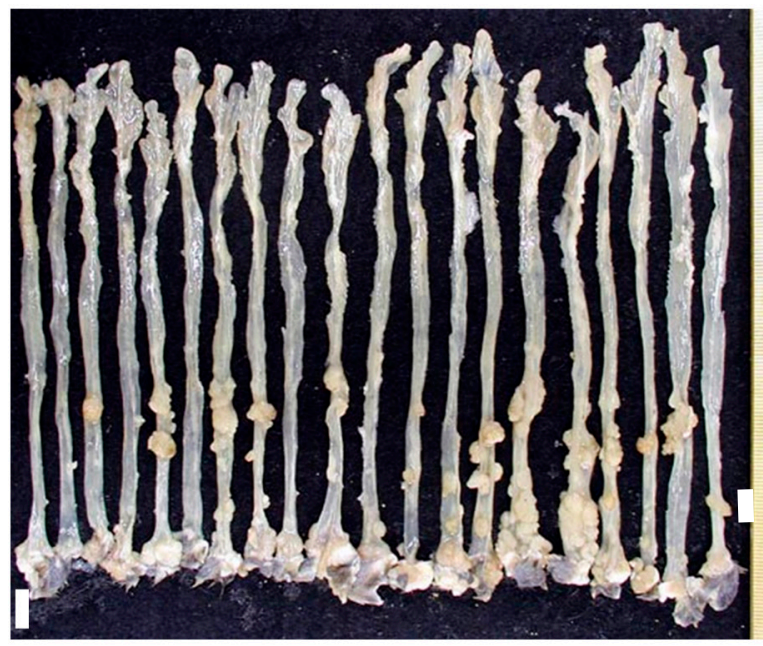

(b)

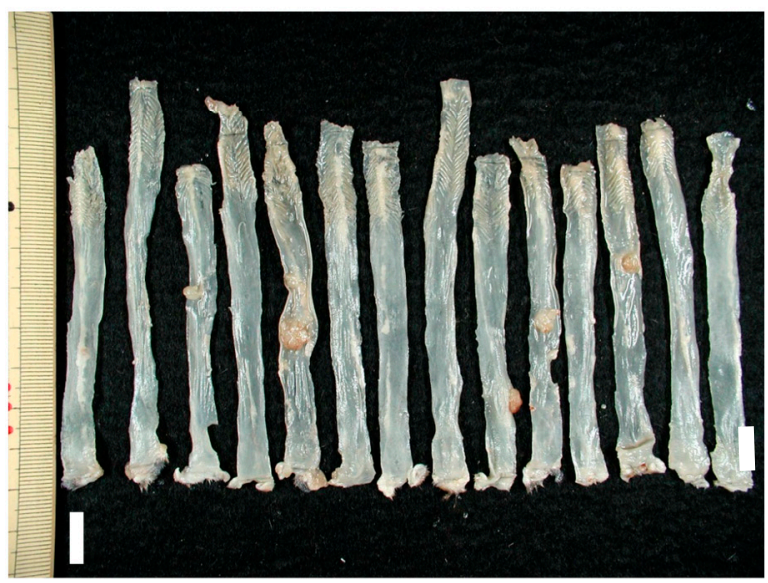

Apoe $^{+/+}$mice

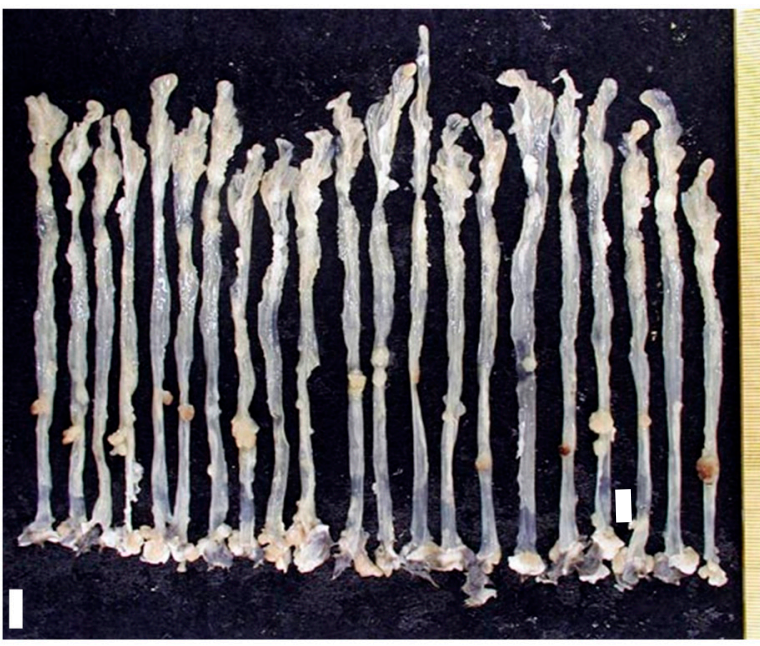

LdII ${ }^{+/+}$mice

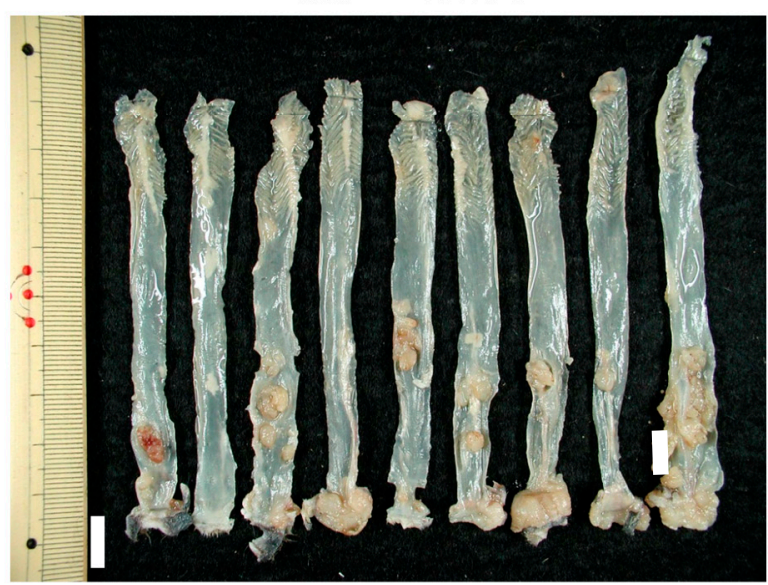

Figure 2. A macroscopic view of the colorectum of (a) the Apoe-deficient and WT mice and (b) the Ldlr-deficient and WT mice. Scales, $10 \mathrm{~mm}$. 
Table 2. Multiplicity and incidence of colorectal preneoplasia and neoplasia.

\begin{tabular}{ccccc}
\hline Pathological Lesions & $\begin{array}{c}\text { Apoe-Deficient } \\
\text { Mice }(\boldsymbol{n}=\mathbf{2 0})\end{array}$ & $\begin{array}{c}\text { WT Mice } \\
(\boldsymbol{n}=\mathbf{2 1})\end{array}$ & $\begin{array}{c}\text { Ldlr-Deficient } \\
\text { Mice }(\boldsymbol{n}=\mathbf{1 4})\end{array}$ & $\begin{array}{c}\text { WT Mice } \\
(\boldsymbol{n}=\mathbf{1 0})\end{array}$ \\
\hline \multirow{2}{*}{ Mucosal ulcer } & $1.25 \pm 1.74^{\mathrm{a}}$ & $0.57 \pm 0.98$ & $2.71 \pm 2.13$ & $3.40 \pm 1.65$ \\
& $(10 / 20,50 \%)$ & $(7 / 21,33 \%)$ & $\left(12 / 14,86^{\circ}\right)$ & $(10 / 10,100 \%)$ \\
\hline \multirow{2}{*}{ Dysplastic crypts } & $1.05 \pm 1.50$ & $0.14 \pm 0.48$ & $0.43 \pm 0.65^{\mathrm{c}}$ & $4.30 \pm 2.67$ \\
& $\left(9 / 20,4 \%^{\mathrm{b}}\right)$ & $(2 / 21,10 \%)$ & $\left(5 / 14,3 \%^{\mathrm{b}}\right)$ & $(9 / 10,90 \%)$ \\
\hline \multirow{2}{*}{ Adenoma (AD) } & $1.00 \pm 1.08$ & $0.62 \pm 0.74$ & $0.29 \pm 0.61^{\mathrm{c}}$ & $2.10 \pm 1.52$ \\
& $\left(11 / 20,55^{\circ}\right)$ & $(10 / 21,48 \%)$ & $\left(3 / 14,2 \%^{\mathrm{b}}\right)$ & $(8 / 10,80 \%)$ \\
\hline \multirow{2}{*}{ Adenocarcinoma (ADC) } & $2.75 \pm 1.48^{\mathrm{c}}$ & $0.62 \pm 0.67$ & $0.50 \pm 0.94^{\mathrm{c}}$ & $3.10 \pm 2.38$ \\
& $\left(19 / 20,9 \%^{\mathrm{d}}\right)$ & $(11 / 21,52 \%)$ & $\left(4 / 14,2 \%^{\mathrm{e}}\right)$ & $(8 / 10,80 \%)$ \\
\hline \multirow{2}{*}{$\mathrm{AD}+\mathrm{ADC}$} & $3.75 \pm-1.83^{\mathrm{c}}$ & $1.24 \pm 0.94$ & $0.79 \pm 1.31^{\mathrm{c}}$ & $5.20 \pm 3.12$ \\
& $(20 / 20,100 \%)$ & $(17 / 21,81 \%)$ & $\left(5 / 14,3 \%^{\mathrm{e}}\right)$ & $(8 / 10,80 \%)$ \\
\hline
\end{tabular}

WT, wild type. ${ }^{\text {a }}$ Mean \pm standard deviation (SD); ${ }^{\mathrm{b}-\mathrm{e}}$ Significantly different from the respective WT mice $\left({ }^{\mathrm{b}} p<0.02,{ }^{\mathrm{c}} p<0.001,{ }^{\mathrm{d}} p<0.005\right.$, and $\left.{ }^{\mathrm{e}} p<0.05\right)$.

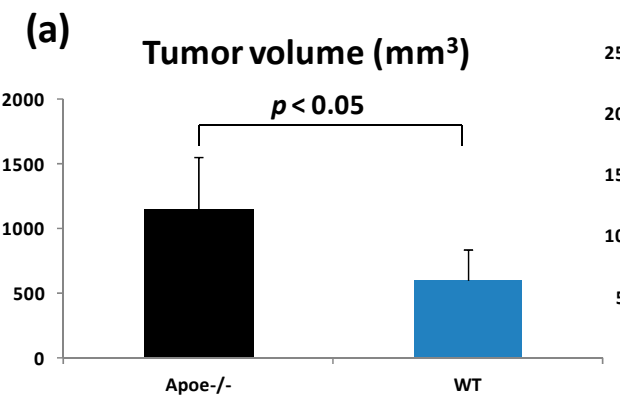

\section{(b) Tumor volume $\left(\mathrm{mm}^{3}\right)$}

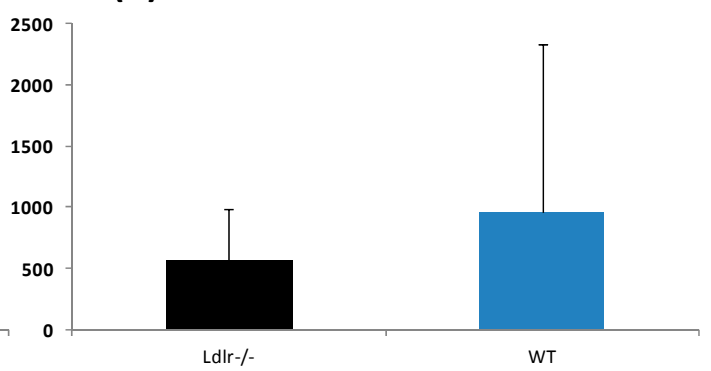

Figure 3. The mean volumes $( \pm \mathrm{SD})$ of colorectal tumors in (a) the Apoe-deficient and WT mice and (b) the Ldlr-deficient and WT mice.

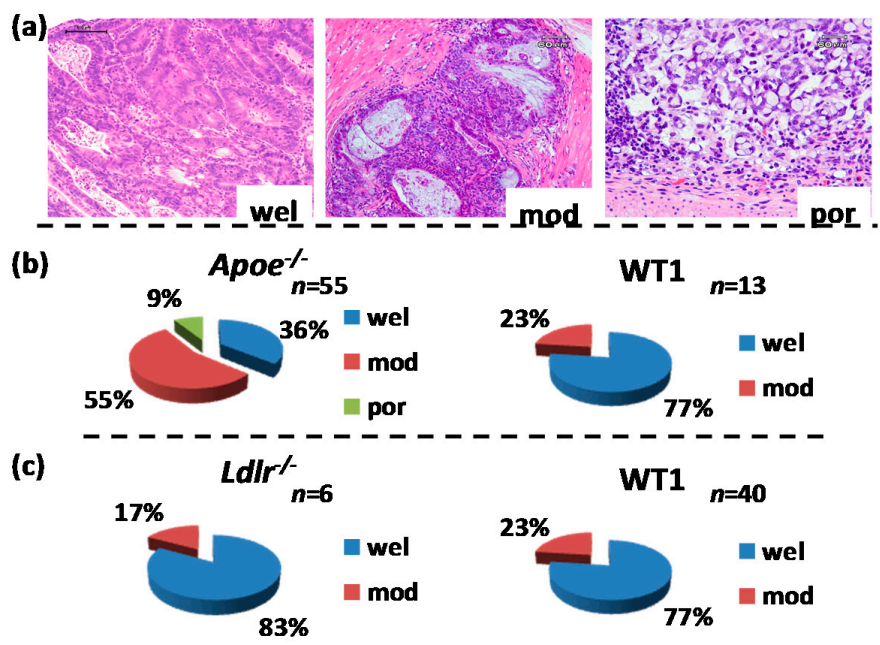

Figure 4. Histopathological analysis of induced colorectal adenocarcinomas. (a) Representative histopathology of colonic adenocarcinomas induced by azoxymethane (AOM) and dextran sodium sulfate (DSS). They were classified into three types of differentiation, well-differentiated (wel), moderately differentiated (mod), and poorly differentiated (por). Hematoxylin and eosin (H \& E) stain used. Bars are $100 \mu \mathrm{m}$ in "wel", $60 \mu \mathrm{m}$ in "mod", and $60 \mu \mathrm{m}$ in "por"; (b) percentages of adenocarcinomas developed in the Apoe-deficient and wild (C57BL/6J) mice that received AOM and DSS; (c) percentage of adenocarcinomas developed in the $L d l r$-deficient and wild (C57BL/6J) mice that received AOM and DSS. 
With regard to the serum biochemistry (Table 3), the cholesterol $(p<0.001)$, very-low-density lipoprotein (VLDL, $p<0.001$ ), and low-density lipoprotein (LDL, $p<0.001$ ) levels in the Apoe-deficient mice were significantly higher than in the WT mice. However, the serum TG, high-density lipoprotein (HDL), glucose, and adiponectin levels were comparable between the genotypes.

Table 3. Serum lipoprotein profiles.

\begin{tabular}{ccccc}
\hline Measurements & $\begin{array}{c}\text { Apoe-Deficient } \\
\text { Mice }(\boldsymbol{n}=\mathbf{2 1})\end{array}$ & $\begin{array}{c}\text { WT Mice } \\
(\boldsymbol{n}=\mathbf{2 0})\end{array}$ & $\begin{array}{c}\text { Ldlr-Deficient } \\
\text { Mice }(\boldsymbol{n}=\mathbf{1 4})\end{array}$ & $\begin{array}{c}\text { WT Mice } \\
(\boldsymbol{n}=\mathbf{1 0})\end{array}$ \\
\hline Serum cholesterol $(\mathrm{mg} / \mathrm{dL})$ & $628 \pm 110^{\mathrm{a}, \mathrm{b}}$ & $132 \pm 23$ & $414 \pm 41^{\mathrm{b}}$ & $131 \pm 21$ \\
Serum triglycerides $(\mathrm{mg} / \mathrm{dL})$ & $106 \pm 16$ & $85 \pm 28$ & $230 \pm 51^{\mathrm{b}}$ & $126 \pm 21$ \\
Serum VLDL $(\mathrm{mg} / \mathrm{dL})$ & $403 \pm 99^{\mathrm{b}}$ & $110 \pm 17$ & $149 \pm 4$ & $120 \pm 4$ \\
Serum LDL $(\mathrm{mg} / \mathrm{dL})$ & $439 \pm 170^{\mathrm{b}}$ & $49 \pm 12$ & $287 \pm 11^{\mathrm{b}}$ & $42 \pm 5$ \\
Serum HDL $(\mathrm{mg} / \mathrm{dL})$ & $36 \pm 32$ & $59 \pm 16$ & $81 \pm 3$ & $63 \pm 35$ \\
Serum glucose $(\mathrm{mg} / \mathrm{dL})$ & $147 \pm 15$ & $175 \pm 25$ & $181 \pm 39$ & $184 \pm 14$ \\
Serum adiponectin $(\boldsymbol{\mu g} / \mathrm{mL})$ & $12.9 \pm 2.3$ & $12.0 \pm 1.7$ & $16.6 \pm 2.1^{\mathrm{b}}$ & $12.1 \pm 3.5$ \\
\hline
\end{tabular}

HDL, high-density lipoprotein; LDL, low-density lipoprotein; VLDL, very-low-density lipoprotein; WT, wild type. ${ }^{a}$ Mean \pm standard deviation (SD); ${ }^{b}$ Significantly different from the respective WT mice $(p<0.001)$.

The mRNA expression of Cox-2 (Figure 5a), Nos2 (Figure 5b), Tnf- $\alpha$ (Figure 5c), Il-1 $\beta$ (Figure 5d), and Il-6 (Figure 5e) in the non-lesional colorectal mucosa of the Apoe-deficient mice was significantly greater than in the WT mice $(p<0.001)$.
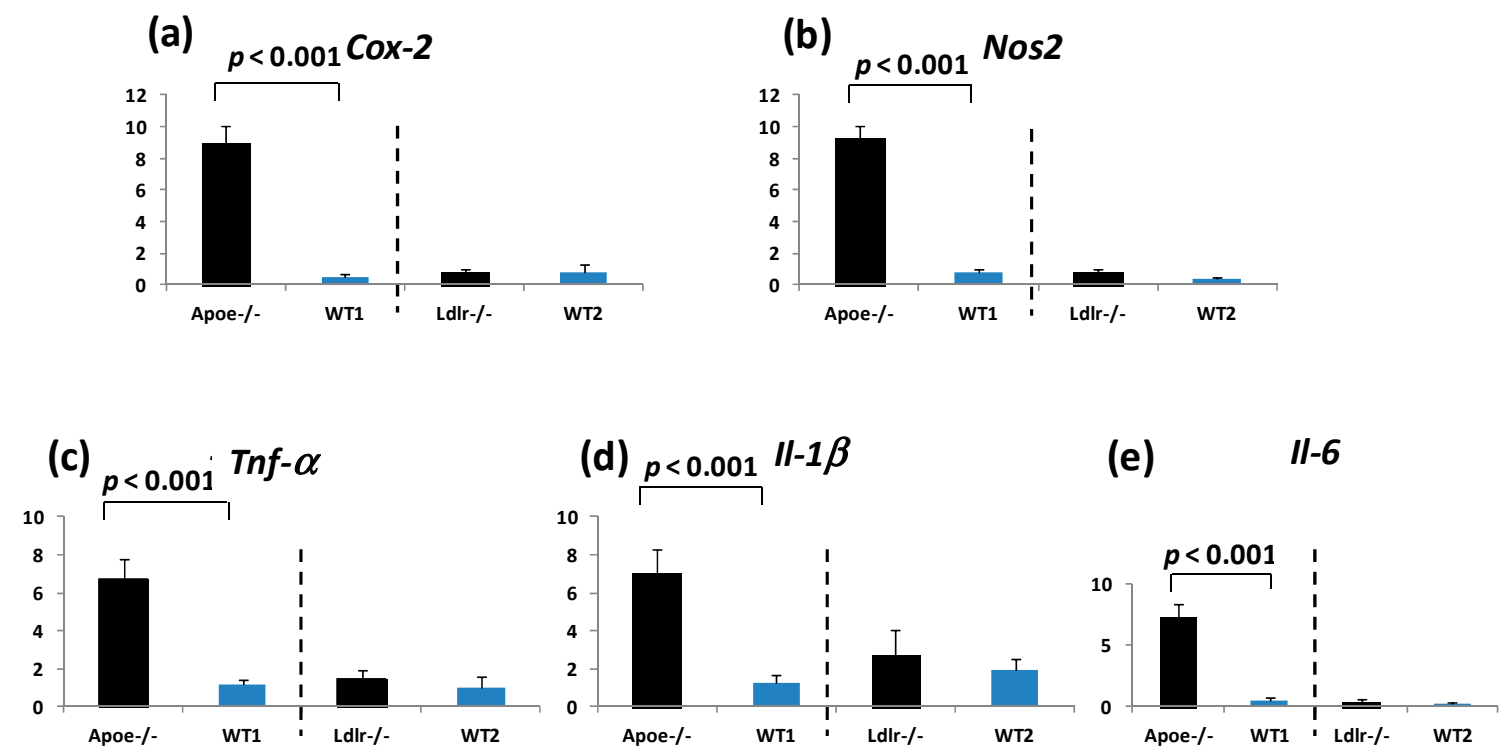

Figure 5. The mRNA expression of (a) Cox-2; (b) Nos2; (c) Tnf- $\alpha$; (d) Il-1 $\beta$; and (e) Il-6 in the colorectal mucosa of the Apoe-deficient, Ldlr-deficient, and their respective wild mice that received AOM and DSS. The mRNA levels of these molecules were measured by Real-Time Quantitative Polymerase Chain Resction. The expression of all five molecules was significantly higher in the Apoe-deficient mice than in the WT mice $(p<0.001)$. The expression of the molecules was slightly but not significantly higher in the $L d l r$-deficient mice than in the WT mice. The expression was normalized to the $\beta$-actin mRNA expression level. The data are represented as the means \pm SD from three independent assays $(n=5$ from each group). $Y$-axis shows expression of the mRNA relative to the "Standard condition" and normalized to $\beta$-actin.

\subsection{AOM/DSS-Induced Colorectal Carcinogenesis in the Ldlr-Deficient Mice (Experiment 2)}

The Ldlr-deficient mice and WT mice tolerated treatment with AOM and 2\% DSS well and survived to week 20 (Figure 1b). At sacrifice, the body, liver, and relative liver weights of the $L d l$-deficient 
mice and WT mice were almost comparable (Table 1). The colon length of the Ldlr-deficient mice was slightly smaller than that of the wild type of mice (Table 1). Treatment with AOM followed by $2 \%$ DSS resulted in the development of colorectal tumors in both genotypes (Figure $2 \mathrm{~b}$ ). The incidences $(p<0.02$ or $p<0.05)$ and multiplicities $(p<0.001)$ of several proliferative colorectal lesions, including DYS, AD, ADC, and AD + ADC, in the Ldlr-deficient mice were significantly lower than in the WT mice (Table 2). The mean volume $\left(569.8 \pm 417.6 \mathrm{~mm}^{3}\right)$ of tumors in the Ldlr-deficient mice was smaller than that in the WT mice $\left(966.2 \pm 1362.8 \mathrm{~mm}^{3}\right)$, but the difference was not statistically significant (Figure 3b). Well- and moderately differentiated ADCs (Figure 4a) developed in the colorectum, but there were no poorly differentiated types (Figure 4c). The incidence and multiplicity of mucosal ulcer in the Ldlr-deficient mice were lower than in the WT mice, but the differences were not statistically significant (Table 2).

The serum levels of cholesterol $(p<0.001)$, TG $(p<0.001)$, LDL $(p<0.001)$, and adiponectin $(p<0.01)$ in the Ldlr-deficient mice were significantly higher than in the WT mice (Table 3). However, the serum VLDL, HDL, and glucose levels were comparable between the genotypes.

As illustrated in Figure 5, the mRNA expression of Cox-2, Nos2, Tnf- $\alpha, \mathrm{Il}-1 \beta$, and Il-6 in the non-lesional colorectal mucosa of the $L d l r$-deficient mice was slightly elevated when compared to the WT mice.

\section{Discussion}

This is the first study, to our knowledge, to examine the susceptibility of inflammation-associated colorectal carcinogenesis in Apoe- and Ldlr-deficient male mice in comparison with their background genotype using our AOM/DSS model [50]. Our findings here suggest that Apoe and Ldlr inversely affect inflammation-associated colorectal carcinogenesis, irrespective of their serum lipoprotein profiles. Surprisingly, the Apoe-deficient mice were much more susceptible to AOM/DSS-induced colorectal carcinogenesis than the WT mice. The mRNA expression levels of two inducible enzymes, Cox-2 and Nos2, and three pro-inflammatory cytokines, Tnf- $\alpha, I l-1 \beta$, and Il-6, in the colorectum of Apoe-deficient mice were much higher than in the Ldlr-deficient mice.

When given AOM and DSS, the colon length of the Apoe-deficient mice or Ldlr-deficient mice was shorter than their respective wild mice (Table 1) without statistical significance. This may be related to the findings of severe colitis and enhancement of colorectal carcinogenesis in the Apoe-deficient mice or $L d l r$-deficient mice. Histopathologic investigation revealed that poorly differentiated ADCs were developed only in the Apoe-deficient mice that received AOM and DSS, but not in the Ldlr-deficient mice and their respective wild mice (Figure $4 \mathrm{~b}, \mathrm{c}$ ). Severe inflammation and increased levels of Cox-2, Nos2, Tnf- $\alpha$, Il-1 $\beta$, and Il- 6 observed in the colorectum of Apoe-deficient mice treated with AOM and DSS may be related to these differences of histopathological findings of ADCs.

The Apoe- and Ldlr-deficient mice, which have elevated serum levels of cholesterol, TG, VLDL, LDL, and/or HDL, are frequently used for research of atherosclerosis and in developing new drugs against atherosclerosis [51,52]. In contrast to the $L d l r$-deficient mice, the Apoe-deficient mice develop atherosclerosis spontaneously without an atherogenic diet. The lipid profiles of these mice differ slightly. For example, hypercholesterolemia in the Apoe-deficient mice is more severe than in the Ldlr-deficient mice. Compared to the WT mice, the serum VLDL level of the Apoe-deficient mice is markedly increased (five-fold that of the WT mice [51]), but the elevation in the VLDL level of the $L d l r$-deficient mice is moderate. While the serum HDL levels of the Apoe-deficient mice are decreased ( $45 \%$ of that in the WT mice [51]), the levels in the Ldlr-deficient mice are modestly increased. The TG level in the Apoe-deficient mice was found to be $68 \%$ higher than that in the WT mice [51]. The different susceptibilities of the two genotypes to AOM/DSS-induced colorectal carcinogenesis may be due to their differing lipid profiles. However, the precise reason for the differences in susceptibility observed in this study is unclear.

Apoe is a major modulator of lipoprotein metabolism, and the allele-specific effects of Apoe on lipoprotein metabolism were reported [53]. Apoe also has other crucial functions, and aberration 
of these functions may lead to carcinogenesis [54-57]. In vitro studies suggest that treatment of the colon cancer cell line, HT29, with Apoe increased the cell polarity by translocating $\beta$-catenin from the cytoplasm to cell-cell adhesion sites [56]. Apoe is able to inhibit cell proliferation and de novo DNA biosynthesis [57]. Functional experiments on Apoe isoforms showed that Apoe4, but not wild-type Apoe, inhibits glycogen synthase kinase (GSK)- $3 \beta$ and increases the amount of active protein kinase $B$ (PKB), which further inactivates GSK-3 $\beta$, leading to enhancement of $\beta$-catenin translocation into nuclei [54]. Nuclear $\beta$-catenin can promote transcription of genes involved in cell survival and division [58-60]. Since patients with UC show impaired lipoprotein metabolism [61], the effect of Apoe polymorphism on the risk of UC development should be investigated.

In the present study, we assayed the mRNA expression of Cox-2, Nos2, TNF- $\alpha, I l-1 \beta$, and Il-6 in the colorectal mucosa of the Apoe-deficient, Ldlr-deficient, and their respective WT mice. The values of the Apoe-deficient mice treated with AOM and DSS were significantly and much greater than the WT mice that received AOM and DSS, suggesting that the Apoe-deficient mice have hyper-inflammation status. Sensitivity to inflammatory stimuli was reported to be greater in Apoe-deficient mice [62] than in Ldlr-deficient mice [63]. This was related to a decrease in the production of certain pro-inflammatory cytokines in the Ldlr-deficient mice, although macrophages maintained an elevated cytokine production capacity $[62,63]$. Apoe involved in cholesterol and lipid metabolism has also altered both innate and adaptive immune responses [64]. Importantly, mice lacking Apoe exhibit increased inflammatory responses and higher mortality following lipopolysaccharide challenge [65]. This may suggest that Apoe has anti-inflammatory effects. Genetic factors have been reported to contribute to the pathophysiology of IBD [66]. Apoe inhibits the production of T lymphocytes and regulates immune reactions by interacting with several cytokines $[67,68]$. Apoe thus plays a key role in regulating the immune response in various autoimmune diseases [69].

Pro-inflammatory cytokines are central mediators of the chronic inflammatory process in several tissues. IL-6 is part of a central pathway in the pathogenesis of chronic inflammation diseases, such as IBD [70], and inflammation-associated colorectal cancer [71-73]. IL-6 trans-signaling is also an independent risk factor for coronary artery disease and is involved in inflammatory processes in vessels [74]. Other cytokines (Tnf- $\alpha$, IL-1 $\beta$, Interferon- $\gamma$ ), inflammatory enzymes (Cox-2, Nos2), nuclear factor (NF)- $\mathrm{kB}$, and signal transducer and activator of transcription 3 (Stat3) are also involved in inflammation-associated colorectal carcinogenesis [72]. Uncontrolled activation of Nf-kB, Stat3, and Wnt- $\beta$-catenin signaling pathways enhances the aberrant proliferation of crypal cells in the sustained inflammatory microenvironment and promotes CRC development [75]. Although we did not assay Stat 3 and Nf-kB in the present study, the mRNA expression of Tnf- $\alpha, I l-1 \beta, I l-6$, Cox-2, and Nos 2 was assayed in the colorectum of Apoe-deficient, Ldlr-deficient, and their respective WT mice treated with AOM and DSS. The expression of all molecules was greater in the Apoe-deficient mice than that of the WT mice. The expression of Nos2, Tnf- $\alpha$, and Il-1 $\beta$ in the Ldlr-deficient mice was slightly higher than that of the WT mice. The Apoe-deficient mice showed even more elevation of these molecules than the $L d l r$-deficient mice. Thus, the Apoe-deficient mice were in a higher-inflammation status compared to the Ldlr-deficient mice. Further studies should investigate colorectal carcinogenesis in Apoe/Ldlr double-knockout mice.

\section{Materials and Methods}

\subsection{Animals, Chemicals, and Diets}

Twenty male five-week-old Apoe ${ }^{-/-}$mice (C57BL/6J background, Jackson Laboratories, Bar Harbor, ME, USA), 14 male five-week-old $\mathrm{Ldlr}^{-/-}$mice (C57BL/6J background, Jackson Laboratories), and 31 male C57BL/6J mice were used in this study. Two experiments were conducted. The experiment for AOM/DSS-induced colorectal carcinogenesis in the Apoe-deficient mice (Experiment 1 ) was conducted using Apoe $e^{-/-}(n=20)$ and C57BL/6J mice $(n=21)$, and contained two experimental groups that were treated with AOM and 1.5\% DSS in their drinking water. Similarly, the experiment for 
AOM/DSS-induced colorectal carcinogenesis in the Ldlr-deficient mice (Experiment 2) was conducted using $\mathrm{Ldlr}^{-/-}(n=14)$ and C57BL/6J mice $(n=10)$, and contained two experimental groups that were given AOM and 2\% DSS in their drinking water. A colorectal carcinogen AOM was obtained from Sigma-Aldrich Chemical (St. Louis, MO, USA), and DSS with a molecular weight of 36,000-50,000 Da (Lot No. 6046H) was purchased from MP Biomedicals (Aurora, OH, USA). AOM was diluted in physiological saline just before injection. DSS for colitis induction was dissolved in water at $1.5 \%(w / v)$ or $2 \%(w / v)$. A pelleted Charles River Formula (CRF)-1 diet (Oriental Yeast, Tokyo, Japan) was used as the basal diet throughout the study. All of the mice were maintained in the animal facility of the University, according to the Institutional Animal Care Guidelines. The animals were housed in plastic cages (three to five mice/cage) with free access to tap water and CRF-1 (Oriental Yeast Co., Ltd., Tokyo, Japan), under controlled conditions of humidity ( $50 \% \pm 10 \%)$, light (12/12 h high/dark cycle), and temperature $\left(23 \pm 2{ }^{\circ} \mathrm{C}\right)$. Study designs were approved by the University and animal handling and procedures were performed in accordance with the Institutional Animal Care Guidelines.

\subsection{Study Design}

In the AOM/DSS-induced colorectal carcinogenesis in the Apoe-deficient mice (Experiment 1), twenty five-week old Apoe-deficient male mice and twenty-one, five-week old C57BL/6J male mice were given a single intraperitoneal (i.p.) injection of AOM $(10 \mathrm{mg} / \mathrm{kg}$ body weight), as shown in Figure 6a. One week after the injection, they received 1.5\% DSS in their drinking water for seven days and then were maintained on a basal diet and tap water for 18 weeks. In the AOM/DSS-induced colorectal carcinogenesis in the $L d l r$-deficient mice (Experiment 2), fourteen five-week-old $L d l r$-deficient male mice and ten five-week-old C57BL/6J male mice were given a single i.p. injection of AOM (10 $\mathrm{mg} / \mathrm{kg}$ body weight), as shown in Figure $6 \mathrm{~b}$. Similar to Experiment 1, they received $2 \%$ DSS in their drinking water for seven days and then were maintained on a basal diet and tap water for 18 weeks. In both experiments, all of the animals were killed by an overdose of ether at week 20 to evaluate the colorectal lesions histopathologically.

(a)

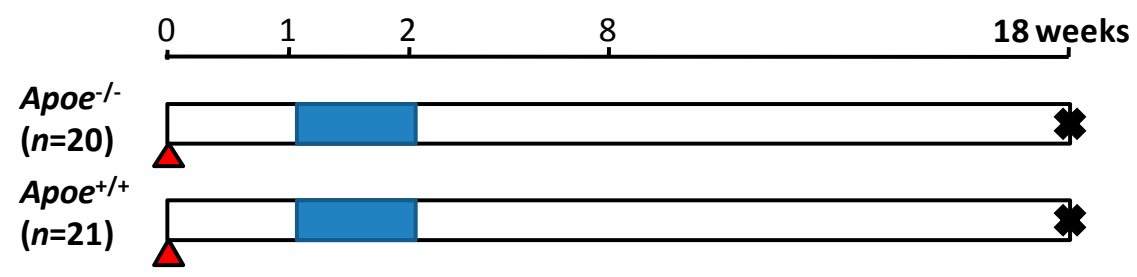

$\triangle$ AOM (10 mg/kg b.w., i.p.) $\square$ 1.5\% DSS in drinking water 4 Sacrifice

(b)

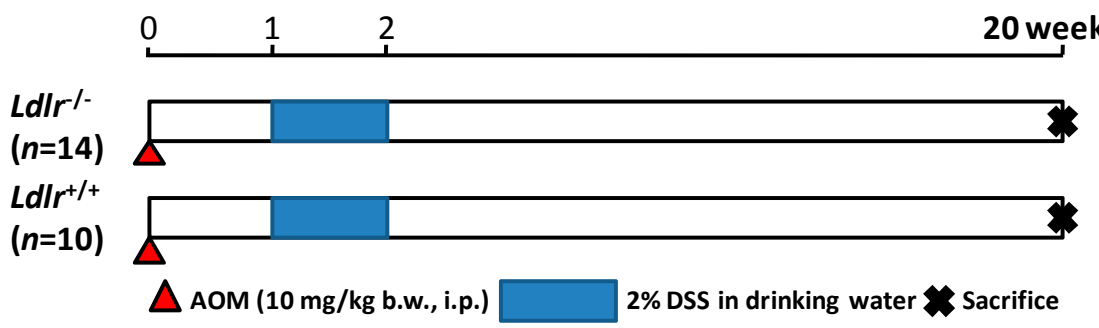

Figure 6. The experimental protocol of (a) the Apoe-deficient and WT mice that received AOM and DSS (Experiment 1) and (b) the Ldlr-deficient and WT mice that received AOM and DSS (Experiment 2). i.p., intraperitoneal.

At sacrifice, complete necropsy was done on all mice. The body and liver weights were measured and processed for a histopathological examination by conventional methods. The colon was flushed with normal saline and then removed. After measuring the length, the colon was cut open longitudinally along the main axis and gently washed with normal saline. The colonrectum 
was macroscopically inspected for the presence of lesions and fixed in $10 \%$ buffered formalin for at least $24 \mathrm{~h}$. A histopathological examination was conducted on paraffin-embedded sections after hematoxylin and eosin ( $\mathrm{H} \& \mathrm{E})$ staining.

\subsection{Real-Time Quantitative Polymerase Chain Reaction (RT-PCR)}

We determined the mRNA expression in the non-lesional colorectal mucosa from five mice of each genotype, Apoe-deficient mice, $L d l$-deficient mice, or their respective wild type of mice.

RNA was extracted from the olorectum and stored at $-80^{\circ} \mathrm{C}$ using TRIzol reagent (Thermo Fisher Scientific, K.K., Yokohama, Japan) according to the manufacturer's protocol. RNA concentration and quality were verified, and reversely transcribed to produce cDNA. Quantitative RT-PCR analyses of Cox-2, Nos2, Tnf- $\alpha, I l-1 \beta$, and Il- 6 were performed with ABI Prism 7500 (Applied Biosystems Japan Ltd., Tokyo, Japan) using TaqMan Gene Expression Assays (Applied Biosystems Japan Ltd., Tokyo, Japan): Cox-2 (Ptgs2), Mm00478374-ml; Nos2 (Mm00440485-ml); Tnf- $\alpha$, Mm00443258-m1; Il-1 $\beta$, Mm00434228-m1; and IL-6, Mm00446190-ml. $\beta$-Actin (Mm00607939-sl) was used to normalize the expression level of the mRNA genes. The cycling protocol of RT-PCR was conducted at a DNA denaturation temperature of $95^{\circ} \mathrm{C}$ for $5 \mathrm{~min}$ and followed by 40 cycles of $95^{\circ} \mathrm{C}$ for $15 \mathrm{~s}, 60{ }^{\circ} \mathrm{C}$ for $20 \mathrm{~s}$, and an elongation temperature $72{ }^{\circ} \mathrm{C}$ for $40 \mathrm{~s}$. Each experiment was performed in triplicate, and data were calculated by $\Delta \Delta C_{\mathrm{t}}$ methods.

\subsection{Clinical Chemistry (Serum Lipid Profiles)}

At sacrifice, blood samples were collected to measure the serum concentrations of total cholesterol, TG, very-low-density lipoprotein (VLDL), LDL, high-density lipoprotein (HDL), glucose, and adiponectin after overnight fasting from 10 or 14 mice in each group. Whole blood anti-coagulated with heparin lithium was taken from the inferior vena cava with a sterile syringe (Terumo, Tokyo, Japan). The serum was obtained by centrifugation (3000 rpm for $10 \mathrm{~min}$ ), and stored at $-80{ }^{\circ} \mathrm{C}$ until measurement. The serum TG and total cholesterol levels were determined using commercial enzymatic assay kits (TG, L-Type WAKO-TG·H; and total cholesterol, L-Type WAKO-CHO·H), obtained from Wako Pure Chemical Industries, Ltd. (Osaka, Japan). The serum levels of HDL, LDL, and VLDL were determined using an HDL and LDL/VLDL Cholesterol Quantitation Kit (BioVision, Inc., Milpitas, CA, USA). The serum glucose level was determined using commercial enzymatic assay kit (Glucose CII-test WAKO, Wako Pure Chemical Industries). These measurements were expressed as mg/dL. The serum adiponectin level $(\mu \mathrm{g} / \mathrm{mL})$ was determined with Mouse/Rat Adiponectin ELISA kits (Otsuka Pharmaceutical Co., Ltd., Tokyo, Japan).

\subsection{Statistical Analysis}

The incidences of colonic lesions between the groups were compared using the chi-square test or Fisher's exact probability test (GraphPad Instat version 3.05; GraphPad Software, San Diego, CA, USA). Other measures expressing mean \pm standard deviation (SD) were statistically analyzed using one-way analysis of variance (ANOVA), followed by the Bonferroni or Tukey-Kramer multiple comparison post-test (GraphPad Instat version 3.05; GraphPad Software). mRNA expression was statistically analyzed by the Kruskal-Wallis test. Differences were considered statistically significant at $p<0.05$.

\section{Conclusions}

Our findings indicate that Apoe and Ldlr are inversely involved in inflammation-associated colorectal carcinogenesis induced by AOM/DSS, irrespective of their serum lipoprotein profiles: the Apoe-deficient mice were much more susceptible to inflammation-associated colorectal carcinogenesis than the WT mice. The mRNA expression levels of two inducible enzymes and certain pro-inflammatory cytokines in the colorectum of Apoe-deficient mice were much more elevated than in the Ldlr-deficient mice. 
Acknowledgments: This work was supported in part by a Grant-in-Aid (201313010A) for the 3rd Terms Comprehensive 10-Year Strategy for Cancer Control from the Ministry of Health, Labour and Welfare of Japan.

Author Contributions: Takuji Tanaka and Masahito Shimizu conceived and designed the experiments; Takeru Oyama and Shigeyuki Sugie performed the experiments; Takeru Oyama and Shigeyuki Sugie analyzed the data; Takuji Tanaka and Masahito Shimizu contributed reagents/materials/analysis tools; Takuji Tanaka and Takeru Oyama wrote the paper.

Conflicts of Interest: The authors declare no conflict of interest.

\section{References}

1. Torre, L.A.; Bray, F.; Siegel, R.L.; Ferlay, J.; Lortet-Tieulent, J.; Jemal, A. Global cancer statistics, 2012. CA Cancer J. Clin. 2015, 65, 87-108. [CrossRef] [PubMed]

2. Jemal, A.; Bray, F.; Center, M.M.; Ferlay, J.; Ward, E.; Forman, D. Global cancer statistics. CA Cancer J. Clin. 2011, 61, 69-90. [CrossRef] [PubMed]

3. Tanaka, T. Colorectal carcinogenesis: Review of human and experimental animal studies. J. Carcinog. 2009, 8, 5. [CrossRef] [PubMed]

4. Reddy, B.S.; Tanaka, T. Interactions of selenium deficiency, vitamin E, polyunsaturated fat, and saturated fat on azoxymethane-induced colon carcinogenesis in male F344 rats. J. Natl. Cancer Inst. 1986, 76, 1157-1162. [PubMed]

5. Reddy, B.S.; Tanaka, T.; Simi, B. Effect of different levels of dietary trans fat or corn oil on azoxymethane-induced colon carcinogenesis in F344 rats. J. Natl. Cancer Inst. 1985, 75, 791-798. [PubMed]

6. Shimizu, M.; Kubota, M.; Tanaka, T.; Moriwaki, H. Nutraceutical approach for preventing obesity-related colorectal and liver carcinogenesis. Int. J. Mol. Sci. 2012, 13, 579-595. [CrossRef] [PubMed]

7. Shirakami, Y.; Shimizu, M.; Kubota, M.; Araki, H.; Tanaka, T.; Moriwaki, H.; Seishima, M. Chemoprevention of colorectal cancer by targeting obesity-related metabolic abnormalities. World J. Gastroenterol. 2014, 20, 8939-8946. [PubMed]

8. Emmons, K.M.; McBride, C.M.; Puleo, E.; Pollak, K.I.; Marcus, B.H.; Napolitano, M.; Clipp, E.; Onken, J.; Farraye, F.A.; Fletcher, R. Prevalence and predictors of multiple behavioral risk factors for colon cancer. Prev. Med. 2005, 40, 527-534. [CrossRef] [PubMed]

9. Ferrari, P.; Jenab, M.; Norat, T.; Moskal, A.; Slimani, N.; Olsen, A.; Tjonneland, A.; Overvad, K.; Jensen, M.K.; Boutron-Ruault, M.C.; et al. Lifetime and baseline alcohol intake and risk of colon and rectal cancers in the European prospective investigation into cancer and nutrition (EPIC). Int. J. Cancer 2007, 121, 2065-2072. [CrossRef] [PubMed]

10. Reddy, B.S. Dietary fat and colon cancer: Animal model studies. Lipids 1992, 27, 807-813. [CrossRef] [PubMed]

11. Wark, P.A.; van der Kuil, W.; Ploemacher, J.; van Muijen, G.N.; Mulder, C.J.; Weijenberg, M.P.; Kok, F.J.; Kampman, E. Diet, lifestyle and risk of K-ras mutation-positive and -negative colorectal adenomas. Int. J. Cancer 2006, 119, 398-405. [CrossRef] [PubMed]

12. Radisauskas, R.; Kuzmickiene, I.; Milinaviciene, E.; Everatt, R. Hypertension, serum lipids and cancer risk: A review of epidemiological evidence. Medicina 2016, 52, 89-98. [CrossRef] [PubMed]

13. Cosnes, J.; Gower-Rousseau, C.; Seksik, P.; Cortot, A. Epidemiology and natural history of inflammatory bowel diseases. Gastroenterology 2011, 140, 1785-1794. [CrossRef] [PubMed]

14. Molodecky, N.A.; Soon, I.S.; Rabi, D.M.; Ghali, W.A.; Ferris, M.; Chernoff, G.; Benchimol, E.I.; Panaccione, R.; Ghosh, S.; Barkema, H.W.; et al. Increasing incidence and prevalence of the inflammatory bowel diseases with time, based on systematic review. Gastroenterology 2012, 142. [CrossRef] [PubMed]

15. Strober, W.; Fuss, I.; Mannon, P. The fundamental basis of inflammatory bowel disease. J. Clin. Investig. 2007, 117, 514-521. [CrossRef] [PubMed]

16. Tanaka, T. Inflammation and cancer. In Cancer: Disease Progression and Chemoprevention; Tanaka, T., Ed.; Research Signpost: Trivandrum, Kerala, India, 2007; pp. 27-44.

17. Tanaka, T.; Kohno, H.; Suzuki, R.; Hata, K.; Sugie, S.; Niho, N.; Sakano, K.; Takahashi, M.; Wakabayashi, K. Dextran sodium sulfate strongly promotes colorectal carcinogenesis in $\mathrm{Apc}^{\mathrm{Min} /+}$ mice: Inflammatory stimuli by dextran sodium sulfate results in development of multiple colonic neoplasms. Int. J. Cancer 2006, 118, 25-34. [CrossRef] [PubMed] 
18. Breslow, J.L. Genetic basis of lipoprotein disorders. J. Clin. Investig. 1989, 84, 373-380. [CrossRef] [PubMed]

19. Dammerman, M.; Breslow, J.L. Genetic basis of lipoprotein disorders. Circulation 1995, 91, 505-512. [CrossRef] [PubMed]

20. Herz, J.; Willnow, T.E. Lipoprotein and receptor interactions in vivo. Curr. Opin. Lipidol. 1995, 6, 97-103. [CrossRef] [PubMed]

21. Turley, S.D.; Spady, D.K.; Dietschy, J.M. Role of liver in the synthesis of cholesterol and the clearance of low density lipoproteins in the cynomolgus monkey. J. Lipid Res. 1995, 36, 67-79. [PubMed]

22. Fong, L.G.; Fujishima, S.E.; Komaromy, M.C.; Pak, Y.K.; Ellsworth, J.L.; Cooper, A.D. Location and regulation of low-density lipoprotein receptors in intestinal epithelium. Am. J. Physiol. 1995, 269, G60-G72. [PubMed]

23. Soued, M.; Mansbach, C.M., Jr. Chylomicron remnant uptake by enterocytes is receptor dependent. Am. J. Physiol. 1996, 270, G203-G212. [PubMed]

24. Bertomeu, A.; Ros, E.; Zambon, D.; Vela, M.; Perez-Ayuso, R.M.; Targarona, E.; Trias, M.; Sanllehy, C.; Casals, E.; Ribo, J.M. Apolipoprotein E polymorphism and gallstones. Gastroenterology 1996, 111, 1603-1610. [CrossRef]

25. Juvonen, T.; Kervinen, K.; Kairaluoma, M.I.; Lajunen, L.H.; Kesaniemi, Y.A. Gallstone cholesterol content is related to apolipoprotein E polymorphism. Gastroenterology 1993, 104, 1806-1813. [CrossRef]

26. Katan, M.B. Apolipoprotein E isoforms, serum cholesterol, and cancer. Lancet 1986, 1, 507-508. [CrossRef]

27. Van Erpecum, K.J.; Carey, M.C. Apolipoprotein E4: Another risk factor for cholesterol gallstone formation? Gastroenterology 1996, 111, 1764-1767. [CrossRef]

28. Van Erpecum, K.J.; van Berge-henegouwen, G.P.; Eckhardt, E.R.; Portincasa, P.; van de Heijning, B.J.; Dallinga-Thie, G.M.; Groen, A.K. Cholesterol crystallization in human gallbladder bile: Relation to gallstone number, bile composition, and apolipoprotein E4 isoform. Hepatology 1998, 27, 1508-1516. [CrossRef] [PubMed]

29. Berkel, J.; Hombergen, D.A.; Hooymayers, I.E.; Faber, J.A. Cholecystectomy and colon cancer. Am. J. Gastroenterol. 1990, 85, 61-64. [PubMed]

30. Bach-Ngohou, K.; Ouguerram, K.; Nazih, H.; Maugere, P.; Ripolles-Piquer, B.; Zair, Y.; Frenais, R.; Krempf, M.; Bard, J.M. Apolipoprotein E kinetics: Influence of insulin resistance and type 2 diabetes. Int. J. Obes. Relat. Metab. Disord. 2002, 26, 1451-1458. [CrossRef] [PubMed]

31. Orchard, T.J.; Eichner, J.; Kuller, L.H.; Becker, D.J.; McCallum, L.M.; Grandits, G.A. Insulin as a predictor of coronary heart disease: Interaction with apolipoprotein E phenotype A report from the Multiple Risk Factor Intervention Trial. Ann. Epidemiol. 1994, 4, 40-45. [CrossRef]

32. Giovannucci, E. Insulin and colon cancer. Cancer Causes Control 1995, 6, 164-179. [CrossRef] [PubMed]

33. Kaaks, R. Nutrition, energy balance and colon cancer risk: The role of insulin and insulin-like growth factor-I. IARC Sci. Publ. 2002, 156, 289-293. [PubMed]

34. Judson, R.; Brain, C.; Dain, B.; Windemuth, A.; Ruano, G.; Reed, C. New and confirmatory evidence of an association between $A p o E$ genotype and baseline C-reactive protein in dyslipidemic individuals. Atherosclerosis 2004, 177, 345-351. [CrossRef] [PubMed]

35. Peng, D.Q.; Zhao, S.P.; Nie, S.; Li, J. Gene-gene interaction of PPAR $\gamma$ and ApoE affects coronary heart disease risk. Int. J. Cardiol. 2003, 92, 257-263. [CrossRef]

36. Erlinger, T.P.; Platz, E.A.; Rifai, N.; Helzlsouer, K.J. C-reactive protein and the risk of incident colorectal cancer. JAMA 2004, 291, 585-590. [CrossRef] [PubMed]

37. Giovannucci, E. Diet, body weight, and colorectal cancer: A summary of the epidemiologic evidence. J. Womens Health 2003, 12, 173-182. [CrossRef] [PubMed]

38. Awad, A.B.; Fink, C.S.; Horvath, P.J. Alteration of membrane fatty acid composition and inositol phosphate metabolism in HT-29 human colon cancer cells. Nutr. Cancer 1993, 19, 181-190. [CrossRef] [PubMed]

39. Nicholson, M.L.; Neoptolemos, J.P.; Clayton, H.A.; Talbot, I.C.; Bell, P.R. Increased cell membrane arachidonic acid in experimental colorectal tumours. Gut 1991, 32, 413-418. [CrossRef] [PubMed]

40. Habenicht, A.J.; Salbach, P.; Goerig, M.; Zeh, W.; Janssen-Timmen, U.; Blattner, C.; King, W.C.; Glomset, J.A. The LDL receptor pathway delivers arachidonic acid for eicosanoid formation in cells stimulated by platelet-derived growth factor. Nature 1990, 345, 634-636. [CrossRef] [PubMed]

41. Habenicht, A.J.; Salbach, P.; Janssen-Timmen, U. LDL receptor-dependent polyunsaturated fatty acid transport and metabolism. Eicosanoids 1992, 5, S29-S31. [PubMed] 
42. Eberhart, C.E.; Coffey, R.J.; Radhika, A.; Giardiello, F.M.; Ferrenbach, S.; DuBois, R.N. Up-regulation of cyclooxygenase 2 gene expression in human colorectal adenomas and adenocarcinomas. Gastroenterology 1994, 107, 1183-1188. [CrossRef]

43. Kargman, S.L.; O'Neill, G.P.; Vickers, P.J.; Evans, J.F.; Mancini, J.A.; Jothy, S. Expression of prostaglandin G/H synthase-1 and -2 protein in human colon cancer. Cancer Res. 1995, 55, 2556-2559. [PubMed]

44. Thun, M.J.; Namboodiri, M.M.; Heath, C.W., Jr. Aspirin use and reduced risk of fatal colon cancer. N. Engl. J. Med. 1991, 325, 1593-1596. [CrossRef] [PubMed]

45. Tjandrawinata, R.R.; Dahiya, R.; Hughes-Fulford, M. Induction of cyclo-oxygenase-2 mRNA by prostaglandin E2 in human prostatic carcinoma cells. Br. J. Cancer 1997, 75, 1111-1118. [CrossRef] [PubMed]

46. Tjandrawinata, R.R.; Hughes-Fulford, M. Up-regulation of cyclooxygenase-2 by product-prostaglandin E2. Adv. Exp. Med. Biol. 1997, 407, 163-170. [PubMed]

47. Caruso, M.G.; Notarnicola, M.; Cavallini, A.; Guerra, V.; Misciagna, G.; di Leo, A. Demonstration of low density lipoprotein receptor in human colonic carcinoma and surrounding mucosa by immunoenzymatic assay. Ital. J. Gastroenterol. 1993, 25, 361-367. [PubMed]

48. Gueddari, N.; Favre, G.; Hachem, H.; Marek, E.; Le Gaillard, F.; Soula, G. Evidence for up-regulated low density lipoprotein receptor in human lung adenocarcinoma cell line A549. Biochimie 1993, 75, 811-819. [CrossRef]

49. Lum, D.F.; McQuaid, K.R.; Gilbertson, V.L.; Hughes-Fulford, M. Coordinate up-regulation of low-density lipoprotein receptor and cyclo-oxygenase-2 gene expression in human colorectal cells and in colorectal adenocarcinoma biopsies. Int. J. Cancer 1999, 83, 162-166. [CrossRef]

50. Tanaka, T.; Kohno, H.; Suzuki, R.; Yamada, Y.; Sugie, S.; Mori, H. A novel inflammation-related mouse colon carcinogenesis model induced by azoxymethane and dextran sodium sulfate. Cancer Sci. 2003, 94, 965-973. [CrossRef] [PubMed]

51. Jawien, J. The role of an experimental model of atherosclerosis: ApoE-knockout mice in developing new drugs against atherogenesis. Curr. Pharm. Biotechnol. 2012, 13, 2435-2439. [CrossRef] [PubMed]

52. Kolovou, G.; Anagnostopoulou, K.; Mikhailidis, D.P.; Cokkinos, D.V. Apolipoprotein E knockout models. Curr. Pharm. Des. 2008, 14, 338-351. [CrossRef] [PubMed]

53. Hagberg, J.M.; Wilund, K.R.; Ferrell, R.E. APO E gene and gene-environment effects on plasma lipoprotein-lipid levels. Physiol. Genom. 2000, 4, 101-108.

54. Cedazo-Minguez, A.; Popescu, B.O.; Blanco-Millan, J.M.; Akterin, S.; Pei, J.J.; Winblad, B.; Cowburn, R.F. Apolipoprotein $\mathrm{E}$ and $\beta$-amyloid (1-42) regulation of glycogen synthase kinase-3 $\beta$. J. Neurochem. 2003, 87, 1152-1164. [CrossRef] [PubMed]

55. Grocott, H.P.; Newman, M.F.; El-Moalem, H.; Bainbridge, D.; Butler, A.; Laskowitz, D.T. Apolipoprotein E genotype differentially influences the proinflammatory and anti-inflammatory response to cardiopulmonary bypass. J. Thorac. Cardiovasc. Surg. 2001, 122, 622-623. [CrossRef] [PubMed]

56. Niemi, M.; Hakkinen, T.; Karttunen, T.J.; Eskelinen, S.; Kervinen, K.; Savolainen, M.J.; Lehtola, J.; Makela, J.; Yla-Herttuala, S.; Kesaniemi, Y.A. Apolipoprotein E and colon cancer. Expression in normal and malignant human intestine and effect on cultured human colonic adenocarcinoma cells. Eur. J. Intern. Med. 2002, 13, 37-43. [CrossRef]

57. Vogel, T.; Guo, N.H.; Guy, R.; Drezlich, N.; Krutzsch, H.C.; Blake, D.A.; Panet, A.; Roberts, D.D. Apolipoprotein E: A potent inhibitor of endothelial and tumor cell proliferation. J. Cell. Biochem. 1994, 54, 299-308. [CrossRef] [PubMed]

58. Behrens, J.; von Kries, J.P.; Kuhl, M.; Bruhn, L.; Wedlich, D.; Grosschedl, R.; Birchmeier, W. Functional interaction of $\beta$-catenin with the transcription factor LEF-1. Nature 1996, 382, 638-642. [CrossRef] [PubMed]

59. Molenaar, M.; van de Wetering, M.; Oosterwegel, M.; Peterson-Maduro, J.; Godsave, S.; Korinek, V.; Roose, J.; Destree, O.; Clevers, H. XTcf-3 transcription factor mediates beta-catenin-induced axis formation in Xenopus embryos. Cell 1996, 86, 391-399. [CrossRef]

60. Pap, M.; Cooper, G.M. Role of glycogen synthase kinase-3 in the phosphatidylinositol 3-Kinase/Akt cell survival pathway. J. Biol. Chem. 1998, 273, 19929-19932. [CrossRef] [PubMed]

61. Ripolles Piquer, B.; Nazih, H.; Bourreille, A.; Segain, J.P.; Huvelin, J.M.; Galmiche, J.P.; Bard, J.M. Altered lipid, apolipoprotein, and lipoprotein profiles in inflammatory bowel disease: Consequences on the cholesterol efflux capacity of serum using Fu5AH cell system. Metabolism 2006, 55, 980-988. [CrossRef] [PubMed] 
62. De Bont, N.; Netea, M.G.; Demacker, P.N.; Verschueren, I.; Kullberg, B.J.; van Dijk, K.W.; van der Meer, J.W.; Stalenhoef, A.F. Apolipoprotein E knock-out mice are highly susceptible to endotoxemia and Klebsiella pneumoniae infection. J. Lipid Res. 1999, 40, 680-685. [CrossRef]

63. Netea, M.G.; Demacker, P.N.; Kullberg, B.J.; Boerman, O.C.; Verschueren, I.; Stalenhoef, A.F.; van der Meer, J.W. Low-density lipoprotein receptor-deficient mice are protected against lethal endotoxemia and severe gram-negative infections. J. Clin. Investig. 1996, 97, 1366-1372. [CrossRef] [PubMed]

64. Laskowitz, D.T.; Lee, D.M.; Schmechel, D.; Staats, H.F. Altered immune responses in apolipoprotein E-deficient mice. J. Lipid Res. 2000, 41, 613-620. [PubMed]

65. Van Oosten, M.; Rensen, P.C.; van Amersfoort, E.S.; van Eck, M.; van Dam, A.M.; Breve, J.J.; Vogel, T.; Panet, A.; van Berkel, T.J.; Kuiper, J. Apolipoprotein E protects against bacterial lipopolysaccharide-induced lethality. A new therapeutic approach to treat gram-negative sepsis. J. Biol. Chem. 2001, 276, 8820-8824. [CrossRef] [PubMed]

66. Waterman, M.; Xu, W.; Stempak, J.M.; Milgrom, R.; Bernstein, C.N.; Griffiths, A.M.; Greenberg, G.R.; Steinhart, A.H.; Silverberg, M.S. Distinct and overlapping genetic loci in Crohn's disease and ulcerative colitis: Correlations with pathogenesis. Inflamm. Bowel Dis. 2011, 17, 1936-1942. [CrossRef] [PubMed]

67. Baitsch, D.; Bock, H.H.; Engel, T.; Telgmann, R.; Muller-Tidow, C.; Varga, G.; Bot, M.; Herz, J.; Robenek, H.; von Eckardstein, A.; et al. Apolipoprotein E induces antiinflammatory phenotype in macrophages. Arterioscler. Thromb. Vasc. Biol. 2011, 31, 1160-1168. [CrossRef] [PubMed]

68. Zhang, H.; Wu, L.M.; Wu, J. Cross-talk between apolipoprotein E and cytokines. Mediat. Inflamm. 2011, 2011, 949072. [CrossRef] [PubMed]

69. Postigo, J.; Genre, F.; Iglesias, M.; Fernandez-Rey, M.; Buelta, L.; Carlos Rodriguez-Rey, J.; Merino, J.; Merino, R. Exacerbation of type II collagen-induced arthritis in apolipoprotein E-deficient mice in association with the expansion of Th1 and Th17 cells. Arthritis Rheum. 2011, 63, 971-980. [CrossRef] [PubMed]

70. Tanaka, T.; Narazaki, M.; Kishimoto, T. IL-6 in inflammation, immunity, and disease. Cold Spring Harb. Perspect. Biol. 2014, 6, a016295. [CrossRef] [PubMed]

71. Tanaka, T. Animal models of carcinogenesis in inflamed colorectum: Potential use in chemoprevention study. Curr. Drug Targets 2012, 13, 1689-1697. [CrossRef] [PubMed]

72. Tanaka, T.; Kochi, T.; Shirakami, Y.; Mori, T.; Kurata, A.; Watanabe, N.; Moriwaki, H.; Shimizu, M. Cimetidine and Clobenpropit Attenuate Inflammation-Associated Colorectal Carcinogenesis in Male ICR Mice. Cancers 2016, 8. [CrossRef] [PubMed]

73. Rath, T.; Billmeier, U.; Waldner, M.J.; Atreya, R.; Neurath, M.F. From physiology to disease and targeted therapy: Interleukin-6 in inflammation and inflammation-associated carcinogenesis. Arch. Toxicol. 2015, 89, 541-554. [CrossRef] [PubMed]

74. Yudkin, J.S.; Kumari, M.; Humphries, S.E.; Mohamed-Ali, V. Inflammation, obesity, stress and coronary heart disease: Is interleukin-6 the link? Atherosclerosis 2000, 148, 209-214. [CrossRef]

75. Bozec, D.; Iuga, A.C.; Roda, G.; Dahan, S.; Yeretssian, G. Critical function of the necroptosis adaptor RIPK3 in protecting from intestinal tumorigenesis. Oncotarget 2016. [CrossRef] [PubMed]

(C) 2016 by the authors; licensee MDPI, Basel, Switzerland. This article is an open access article distributed under the terms and conditions of the Creative Commons Attribution (CC-BY) license (http://creativecommons.org/licenses/by/4.0/). 